Article

http://dergipark.gov.tr/ataunizfd

\title{
Değişik Seviyelerde Humat İçeren Rasyonların ve Canlı Ağırlı̆̆ın Yumurtacı Tavuklarda Performans ve Yumurta Kalite Özellikleri Üzerine Etkileri
}

\author{
Şaban ÇELEBi \\ Atatürk Üniversitesi, Ziraat Fakültesi, Zootekni Bölümü, Erzurum, Türkiye \\ (Sorumlu yazar e-mail: scelebi@ atauni.edu.tr) \\ DOI: 10.17097/ataunizfd.562970 \\ Kabul Tarihi (Accepted Date): 01.07.2019
}

Gelis Tarihi (Received Date): 10.05.2019

\begin{abstract}
ÖZ: Farklı düzeylerde humat (\%0.0, 0.15 ve 0.30$)$ katılarak olușturulan rasyonların ve canlı ağırlığın (hafif $=1400-1500 \mathrm{~g}$, orta $=1500-1600 \mathrm{~g}$ ve ağır $=1600<\mathrm{g}$ ) yumurtacı tavuklarda performans ve yumurta kalite özellikleri üzerine etkilerini belirlemek amacıyla yürütülen çalışmada, üç grupta toplam 216 adet 28 haftalık yaşta Lohmann yumurtacı tavuk kullanılmış ve araştırma 16 hafta sürdürülmüsstür. Humat seviyesinin yem tüketimi ve yemden yararlanma oranı hariç diğer performans özelliklerini etkilemediği belirlenmiştir. Çalışmada; \%0.0, 0.15 ve 0.30 humat içeren rasyonlarla beslenen gruplarda sırasıyla, yem tüketimi $125.8,120.8$ ve $123.4 \mathrm{~g}$, yemden yararlanma oranı ise $2.08,2.0$ ve 2.0 olarak saptanmıștır. Canlı ağırlık, performans özelliklerinin bütününü önemli derecede etkilediği tespit edilmiştir. Canlı ağıllık arttıkça performans özelliklerinde de artış gözlenmesine rağmen, canlı ağırlığı düșük olan hayvanlardan olușturulan hafif grup bir kg yumurta verimi için daha az yem tüketmiștir. Deneme geneli itibariyle hafif, orta ve ağır grupların sırasıyla; yem tüketimi $119.5,123.2$ ve $127.3 \mathrm{~g}$; yumurta verimi $\% 76.782 .2$ ve 88.9 ; yumurta ağırlı̆̆ $61.3,60.2$ ve $62.7 \mathrm{~g}$; yemden yararlanma oranı $1.98,2.05$ ve 2.08 olarak saptanmıştır $(\mathrm{P}<0.01)$. Humat seviyesi ve canlı ağırlık arasındaki interaksiyonun performans özellikleri üzerine etkisi istatistiksel olarak önemsiz bulunmuștur. Sarı rengi ve sarı indeksi hariç yumurta kalite özellikleri humat seviyesinden etkilenmemiştir. Ayni zamanda canlı ağırlığın yumurta kalite parametrelerini etkilemediği tespit edilmiștir. Humat seviyesi ve canlı ağılık arasındaki interaksiyonun ak indeksi ve haugh birimi hariç diğer yumurta kalite özellikleri üzerine etkisi istatistiksel olarak önemsiz bulunmuştur. Sonuç olarak, humat içeren rasyonlarla beslenen gruplarda ve hafif grupta performans özelliklerinin en önemlisi olan yemden yararlanmanın diğer gruplardan daha iyi $(\mathrm{P}<0.01)$ olduğu tespit edilmiștir.
\end{abstract}

Anahtar kelimeler: Yumurtacı tavuk, Humat, Canlı ağırlık, Performans, Yumurta kalitesi

Effects of Humate Supplemented Diets and Body Weight On Performance and Egg Quality Parameters of Laying Hens

ABSTRACT: This experement was conducted to determine the effects of different levels of dietary humate $(0.0,0.15,0.30 \%)$ suplementation and body weight (light $=1400-1500 \mathrm{~g}$, medium $=1500-1600$, heavy $=1600<\mathrm{g}$ ) on laying performance and egg quality parameters of layers. A total of 216 Lohmann layers at age of 28 weeks were utilized as animal material. The experimental period lasted for 16 weeks. Except for feed consumption and feed conversion ratio, humat levels did not affect laying performance parameters. The Feed consumption and feed conversion ratio for groups of feeding humate suplementation diet $(0.0,0.15,0.30 \%)$ were found to be $125,8,120,8,123,4 \mathrm{~g}$ and 2,08, 2,0 and 2,0, respectively. All of the performance parameters were significantly affected by body weight. As body weight linearly increased, performance parameters also increased. But laying hens in light group consumed less feed for one kg egg pruduction than those of medium and heavy groups. Avarage daily feed intake (g), hen-day egg production (\%), egg weight (g) and feed conversion ratio for light, medium and heavy groups were 119.5, 123.18, 127.3; 76.672, $82.190,88.908 ; 61.29,60.21,62.69$ and $1.98,2.05,2.08$, respectively. The effect of humat level by body weight interaction on performance parameters was not found statistically significant. Except for egg yolk color and yolk index, egg quality parameters were not affected by humate levels. In addition, body weight had no significant effect on egg quality traits. Hens fed with diets including humate at differentlevels have produced more intensively coloured egg yolks than that of control group consumed feed without dietary humate. Although humat level by body weight interaction effected albumen index and Haugh unit, other egg quality parameters were not affected statistically by this interaction. As a result, groups fed with diets including dietary humate at different levels and light group consumed less feed per kg egg pruduction than those of other groups.

Keywords: Laying hen, Humate, Body weight, Performance, Egg quality

\section{GİRiş}

Hayvansal üretim öncelikle insanlara sağlıklı ve nitelikli gıdalar üretmek için yapılır. Antibiyotiklerin insan ve hayvan sağlığı üzerindeki zararlı etkileri anlaşılmasından sonra verimi ve sindirimi artırmak amaciyla hormonlar, enzimler, probiyotikler ve humatlar gibi bazı yem katkı maddeleri daha fazla ilgi çeker hale gelmiştir. Hayvan besleme ve biyoteknoloji alanlarında sağlanan ilerlemelere paralel olarak son yıllarda çeşitli yem katkı maddelerinin kullanımı, üzerinde en çok durulan konuların başında gelmektedir. Hayvancılığı gelişmiş ülkelerde ekonomiyi olumlu yönde etkileyecek ve alternatif olabilecek yeni doğal kaynaklar üzerinde uzun yıllardan beri çalışmaların yapıldığı bilinmektedir. Kanatlılarda bağırsak mikroflorasını düzenlemek, verimi ve yemden yararlanmayı iyileştirmek, büyümeyi teşvik etmek amacıyla ve insan sağlı̆ğına zarar verici hiçbir unsur taşımamaları, doğal yolla elde edilmeleri nedeniyle probiyotik ve humatların antibiyotiklere alternatif yem katkı maddeleri olarak kullanımları giderek artmaktadır (Bailey vd., 1996; Ceylan vd., 2003; Macit vd., 2005). Humatların hayvan beslemede kullanımları bilinmektedir (Parks vd., 1996; Anonim, 2002). Humatlar, organik maddelerin toprak içerisinde parçalanma ürünleri olan karbonhidrat, aminoasit ve fenoller gibi bazı 
Değişik Seviyelerde Humat İçeren Rasyonların ve Canlı Ağırlı̆ın Yumurtacı Tavuklarda Performans ve Yumurta Kalite Özellikleri Üzerine Etkileri

maddelerin meydana getirdiği humustan köken alan humik, fulvik ve ulmik asitler ile $\mathrm{Al}, \mathrm{Na}, \mathrm{K}, \mathrm{Fe}, \mathrm{Ca}$, $\mathrm{Mg}, \mathrm{Mn}, \mathrm{P}, \mathrm{Cu}$, ve $\mathrm{Zn}$ gibi minerallerden meydana gelmektedir (Bailey et al., 1996; Levinsky, 1997; Küçükersan vd., 2003; Macit vd., 2005).

Humatlar, elektron transferi yapabilmeleri sayesinde bazı metal iyonları ile şelat oluşturarak birçok toksik bileşiğin vücuttan kolaylıkla atılmalarını sağlarlar. Böylece vücutta elektrolit dengesi sağlarlar (Küçükersan vd., 2003; Yörük vd., 2004; Hayırlı vd., 2005; Öztürk ve Coşkun, 2005). Humat bileşikleri hayvanlar üzerindeki olumlu etkilerini; patojen bakterilerin ve mantarların gelişimini engelleyerek, sindirim kanalında optimum $\mathrm{pH}$ 'in muhafazasını sağlamak suretiyle sindirimi iyileştirerek, kalsiyum ve iz elementlerden yararlanarak, fagositik aktiviteyi artırarak ve bağışıklık sistemini güçlendirerek göstermektedirler (Ceylan vd., 2003; Yörük vd., 2004). Birçok çalışmada tavuk rasyonlarına humat ilavesinin yumurta verimini artırdığı, yemden yaralanmayı iyileştirdiği, ölüm oranını azalttığı tespit edilmiştir (Bailey et al., 1996; Ceylan vd., 2003; Küçükersan vd., 2003; Yörük vd., 2004; Macit vd., 2005; Öztürk ve Coşkun, 2005). Parks et al. (1996), humatların yemlerin pelet kalitesini, yemden yararlanma ve bazı bağışıklık parametrelerini iyileştirdiğini bildirmişler ve bunu humatların yemdeki elektrolit dengesizliğinden kaynaklanan olumsuzlukları hafifletmesine bağlamışlardır.

Yumurta özellikleri genetik yap1, beslenme, sağlık, hayvanların yaşı, barındırılma, yemlerin depolanma koşulları ve süresi gibi bazı faktörler tarafindan etkilenmektedir. Tavukların yaşı ilerledikçe kabuk kalitesi düşmekte yumurta ağırlığı, sarı ve ak ağırlıkları ise artmaktadır (Humik et al., 1977; Roland, 1979; Arafa et al., 1982). Altan vd. (1998), canlı ağırlığın bıldırcınlarda performans ve yumurta kalite özellikleri üzerine etkisini araştırdıkları çalışmada, canlı ağırlıktaki artışa bağlı olarak yumurta ağırlığının arttığını, kabuk kalitesi, haugh birimi ve yumurta veriminin değişmediğini tespit etmişlerdir. Harms et al. (1982), hafif, orta ve ağır yumurtacı tavuklarda günlük yem tüketiminin ve yumurta ağırlığının ağır gruplarda daha fazla olduğunu, yemden yararlanmanın ise vücut ağırlığındaki artışa bağlı olarak kötüleştiğini tespit etmişlerdir.

Yumurtacı tavuk rasyonlarına değişik oranlarda ilave edilen humatın ve farklı canlı ağırlıkların performans ve yumurta kalitesi üzerine etkisinin incelendiği çalışmadan elde edilen sonuçlar, bu konu üzerine bugüne kadar yapılmış sınırlı sayıda araştırma sonuçlarıyla mukayese edilerek yumurtacı tavuk rasyonlarına canlı ağırlığa göre katılabilecek en uygun humat oranı belirlenmeye çalışılmıştır.

\section{MATERYAL VE METOT}

\section{Havyan Materyali}

Hayvan materyali olarak, 28 haftalık yaşta 216 adet Lohmann beyaz yumurtacı tavuk kullanılmıştır. Bileşimi ve besin madde kompozisyonu Çizelge 1'de verilen kafes tavuğu yumurta yemine $\% 0,0.15$ ve 0.30 humat katılarak oluşturulan rasyonlar kullanılmıştır. Çalışmada; her grupta 72 hayvan bulunan 3 grup (\%0, $0.15, \quad 0.30$ humat içeren rasyonla beslenen) oluşturulmuştur. Her grup 3 alt gruba (hafif $=1400$ $1500 \mathrm{~g}$, orta $=1500-1600 \mathrm{~g}$ ve ağ $1 \mathrm{r}=1600>\mathrm{g}$ ), yine her alt grupta 6 tekerrür (her kafestete 4 hayvan) olacak şekilde tam şansa bağlı deneme planına göre düzenlenmiştir. Bazal yem, kontrol grubu (\%0.0 humat), diğer 2. ve 3. gruplar ise bazal yeme sirasiyla $\% 0.15$ ve 0.30 düzeylerinde humat (Farmagületör $\mathrm{DRY}^{\mathrm{TM}}$.Humat, Farmavet International Inc., Kocaeli 41400, Türkiye) ilave edilerek oluşturulan rasyonlarla, bir haftası deneme yemlerine alıştırma periyodu olmak üzere toplam 16 hafta süreyle beslenmişlerdir.

Çizelge 1. Araştırmada kullanılan bazal yemin bileşimi ve besin madde kompozisyonu

\begin{tabular}{|l|c|l|c|}
\hline \multicolumn{2}{|c|}{ Bazal yemin bilesimi (\%) } & \multicolumn{2}{l|}{ Bazal yemin besin madde kompozisyonu ${ }^{1}(\%)$} \\
\hline Soya küspesi & 22.25 & Ham protein & 15.91 \\
\hline Misır & 49.10 & Kuru madde & 91.97 \\
\hline Buğday & 5.00 & Ham yă & 3.89 \\
\hline Arpa & 4.00 & Ham selüloz & 6.18 \\
\hline Kepek & 6.00 & Ham kül & 13.31 \\
\hline Hayvansal yă & 2.00 & Metabolik Enerji, $\mathrm{kcal} / \mathrm{kg}$ & 2650.00 \\
\hline Et-kemik unu & 2.20 & & \\
\hline Mermer tozu & 8.60 & & \\
\hline Tuz & 0.25 & & \\
\hline${ }^{*}$ Vitamin premiksi & 0.25 & & \\
\hline${ }^{* *}$ Mineral premiksi & 0.15 & & \\
\hline L-lisin & 0.10 & & \\
\hline DL-metiyonin & 0.10 & & \\
\hline
\end{tabular}

*: Her kg vitamin premiksi: vitamin A 6000000 I.U., vitamin D3 600000 I.U., vitamin E $8000 \mathrm{mg}$, vitamin $\mathrm{K}_{3} 2000 \mathrm{mg}, \mathrm{B}_{1} 1200 \mathrm{mg}, \mathrm{B}_{2}$ $3200 \mathrm{mg}$, niasin $10000 \mathrm{mg}$, kalsiyum-D- pantotenat $6000 \mathrm{mg}$, vitamin $\mathrm{B}_{6} 2000 \mathrm{mg}$, vitamin $\mathrm{B}_{12} 8 \mathrm{mg}$, folik asit $400 \mathrm{mg}$, biotin $20 \mathrm{mg}$, kolin klorid $160000 \mathrm{mg}$.

**: Her kg mineral premiksinde: Mn 80000 mg, Fe 60000 mg, Zn 6000 mg, Cu 5000 mg, Co 200 mg, I 1 000mg, Se 150 mg, CaCO $450 \mathrm{mg}$.

1: Çizelge değerleri üzerinden hesaplanmıştır. 
Canlı ağırlıklar, deneme boyunca 14 günde bir alt gruplarda bulunan tavukların tartılmasiyla belirlenmiştir. Yem tüketimlerinin belirlenmesi için, yemler önceden tartılarak hayvanlara ad-libitum olarak verilmiş ve her 14 günde yem tüketimleri tespit edildikten sonra, ortalama bireysel günlük yem tüketimleri belirlenmiştir. Yumurta verimleri; her 14 günde yüzde olarak hesaplanmıştır. Yemden yararlanma oranı; her gruba ait alt grupların 14 günlük yemden yararlanma oranları hesap edilmiştir. Yumurta ağırlıkları ise, her gün toplanan yumurtaların 14 günde bir oda sıcaklığında bir gün bekletildikten sonra tartılması ile elde edilmiştir.

\section{Yumurta Kalite Özelliklerinin belirlenmesi}

Yumurta kalite özelliklerini (şekil indeksi, kırılma mukavemeti, kabuk kalınlığı, sarı rengi, ak indeksi, sar1 indeksi, Haugh birimi) belirlemek amacıyla ayda bir her gruptan 18 adet yumurta örneği alınmıştır. Toplanan yumurtalar tartıldıktan sonra şekil indeksi ölçme aleti ile şekil indeksleri (\%), kırılma mukavemeti ölçüm aleti ile kırılma mukavemetleri $\left(\mathrm{kg} / \mathrm{cm}^{2}\right)$ ölçülmüştür. Yumurta sarı ve ak yüksekliği mikrometre ile, sarı çapı, ak uzunluğu ve genişliği ise kumpas ile ölçülmüştür (Kaya ve
Macit, 2012). Bu değerlerden yararlanarak sar1 indeksi, ak indeksi ve Haugh birimi değerleri hesaplanmıştır. Kabuk kalınlığı yumurtaların sivri, küt ve orta kısımlarından olmak üzere kabuk zarı çıkarılıp, mikrometre $\left(\mu \mathrm{m}^{2}\right)$ ile kalınlıkları ölçülmüş ve ortalamaları alınmıştır. Yumurta sarı rengi ise Roche renk yelpazesi ile tespit edilmiştir.

\section{İstatistik Analizler}

Denemede elde edilen verilerin istatistik analizinde General Linear Model (GLM) kullanılmıştır (SAS, 1998). Linear modelde; üç humat seviyesi, üç canlı ağırlık ve zamanın etkileri ile aralarındaki etkileşimin etkisi sabit faktörler, gruplar içindeki kafesler ise (blok) tesadüf faktörleri olarak tanımlanmıştır.

\section{BULGULAR VE TARTIŞMA}

Değişik seviyelerde humat içeren rasyonlarla beslenen farklı canlı ağırlık grubundaki yumurtacı tavukların performans özellikleri olarak ele alınan yem tüketimi, yumurta verimi, yumurta ağırlığı, yemden yararlanma oranı ve canlı ağırlıklarına ait ortalamalar ve standart hatalar ile çoklu karşılaştırma testi sonuçları Çizelge 2'de verilmiştir.

Çizelge 2. Deneme gruplarının performans özelliklerine ait ortalamalar

\begin{tabular}{|c|c|c|c|c|c|c|}
\hline \multicolumn{2}{|c|}{ Muamele } & \multicolumn{5}{|c|}{ Performans Özellikleri } \\
\hline $\begin{array}{l}\text { Humat } \\
\text { Seviyesi } \\
(\%)\end{array}$ & $\begin{array}{c}\text { Ağırlık } \\
(\mathrm{g})\end{array}$ & $\begin{array}{c}\text { Yem } \\
\text { tüketimi } \\
(\mathrm{g} / \text { gün})\end{array}$ & $\begin{array}{c}\text { Yumurta } \\
\text { Verimi(\%) }\end{array}$ & $\begin{array}{c}\text { Yumurta } \\
\text { Ağırlığı (g) }\end{array}$ & \begin{tabular}{cc}
\multicolumn{2}{c}{ Yemden Yararlanma } \\
Oranı $\quad(\mathrm{kg} \mathrm{yem} / \mathrm{kg}$ \\
yumurta)
\end{tabular} & $\begin{array}{c}\text { Canlı } \\
\text { Ağırlık (g) }\end{array}$ \\
\hline \multirow[t]{3}{*}{$\% 0$} & Hafif & $122.1^{\mathrm{b}}$ & $78.4^{\mathrm{b}}$ & 60.5 & $2.0^{\mathrm{b}}$ & $1460^{c}$ \\
\hline & Orta & $126.9^{\mathrm{ab}}$ & $79.9^{\mathrm{b}}$ & 60.3 & $2.1^{\mathrm{a}}$ & $1534^{\mathrm{b}}$ \\
\hline & Ăğır & $128.4^{\mathrm{a}}$ & $90.8^{\mathrm{a}}$ & 60.9 & $2.1^{\mathrm{a}}$ & $1694^{\mathrm{a}}$ \\
\hline \multicolumn{2}{|c|}{ Ortalama } & $125.8^{A_{ \pm} .65}$ & $83.0 \pm .89$ & $61.0 \pm .49$ & $2.08^{A_{1}} \pm .01$ & $1563 \pm 6.4$ \\
\hline \multirow[t]{3}{*}{$\% 0.15$} & Hafif & $117.3^{\mathrm{c}}$ & $74.4^{\mathrm{b}}$ & $59.9^{\mathrm{b}}$ & 1.9 & $1457^{\mathrm{c}}$ \\
\hline & Orta & $120.9^{\mathrm{b}}$ & $83.9^{\mathrm{a}}$ & $61.3^{\mathrm{a}}$ & 2.0 & $1549^{\mathrm{b}}$ \\
\hline & Ăğ1r & $124.3^{\mathrm{a}}$ & $87.2^{\mathrm{a}}$ & $61.3^{\mathrm{a}}$ & 2.0 & $1643^{\mathrm{a}}$ \\
\hline \multicolumn{2}{|c|}{ Ortalama } & $120.8^{C_{ \pm} .65}$ & $81.8 \pm .89$ & $61.2 \pm .49$ & $2.00^{B} \pm .01$ & $1550 \pm 6.4$ \\
\hline \multirow[t]{3}{*}{$\% 0.30$} & Hafif & $119.2^{\mathrm{b}}$ & $77.2^{\mathrm{c}}$ & $59.9^{\mathrm{b}}$ & $1.9^{\mathrm{b}}$ & $1458^{\mathrm{c}}$ \\
\hline & Orta & $121.7^{\mathrm{b}}$ & $82.8^{\mathrm{b}}$ & $60.2^{\mathrm{b}}$ & $2.0^{\mathrm{ab}}$ & $1531^{\mathrm{b}}$ \\
\hline & Ăğır & $129.1^{\mathrm{a}}$ & $88.7^{\mathrm{a}}$ & $61.7^{\mathrm{a}}$ & $2.1^{\mathrm{a}}$ & $1655^{\mathrm{a}}$ \\
\hline \multicolumn{2}{|c|}{ Ortalama } & $123.4^{\mathrm{B}} \pm .65$ & $82.9 \pm .89$ & $61.9 \pm .49$ & $2.00^{B} \pm .01$ & $1548 \pm 6.4$ \\
\hline \multicolumn{2}{|c|}{$\mathrm{s} \bar{x}$} & 1.12 & 1.54 & 0.38 & 0.02 & 11.03 \\
\hline
\end{tabular}

\begin{tabular}{|c|c|c|c|c|c|}
\hline \multicolumn{6}{|l|}{$\mathrm{P}$} \\
\hline Humat seviyesi & 0.000 & 0.580 & 0.584 & 0.000 & 0.207 \\
\hline Ağırlık & 0.000 & 0.000 & 0.000 & 0.000 & 0.000 \\
\hline Seviye $\times$ ağırlık & 0.121 & 0.073 & 0.093 & 0.673 & 0.040 \\
\hline Zaman & 0.000 & 0.000 & 0.000 & 0.000 & 0.000 \\
\hline Seviye $\times$ zaman & 0.013 & 0.991 & 0.979 & 0.008 & 0.902 \\
\hline A ğırlık $\times$ zaman & 0.628 & 0.202 & 0.994 & 0.552 & 0.991 \\
\hline Seviye $\times$ ăgrlık×zaman & 0.737 & 0.998 & 0.937 & 0.567 & 1.000 \\
\hline
\end{tabular}


Değişik Seviyelerde Humat İçeren Rasyonların ve Canlı Ağırlı̆ın Yumurtacı Tavuklarda Performans ve Yumurta Kalite Özellikleri Üzerine Etkileri

Çizelge 3. Deneme gruplarının canlı ağırlığa göre performans özelliklerine ait ortalamalar

\begin{tabular}{|l|c|c|c|c|c|}
\hline \multirow{2}{*}{ Performans Özellikleri } & \multicolumn{2}{|c|}{ Canlı Ağırlıklar } & \multirow{2}{*}{$\mathrm{S} \bar{x}$} & \multirow{2}{*}{$\mathrm{P}$} \\
\cline { 2 - 5 } & Hafif & Orta & Ağır & & \\
\hline Yem tüketimi $(\mathrm{g})$ & $119.6^{\mathrm{c}}$ & $123.2^{\mathrm{b}}$ & $127.3^{\mathrm{a}}$ & 0.64 & $* *$ \\
\hline Yumurta verimi $(\%)$ & $76.67^{\mathrm{c}}$ & $82.19^{\mathrm{b}}$ & $88.91^{\mathrm{a}}$ & 0.88 & $* *$ \\
\hline Yumurta ağırlığı (g) & $61.3^{\mathrm{b}}$ & $60.2^{\mathrm{b}}$ & $62.70^{\mathrm{a}}$ & 0.49 & $* *$ \\
\hline Yemden yaralanma oranı & $1.98^{\mathrm{b}}$ & $2.05^{\mathrm{a}}$ & $2.08^{\mathrm{a}}$ & 0.01 & $* *$ \\
\hline Canlı ağırlık (g) & $1458.160^{\mathrm{c}}$ & $1537.908^{\mathrm{b}}$ & $1663.939^{\mathrm{a}}$ & 6.37 & $* *$ \\
\hline
\end{tabular}

a, b, c: Aynı satırda farklı harflerle gösterilen ortalamalar arasındaki farklar önemlidir. $* *: \mathrm{P}<0.01$.

Değişik seviyelerde humat içeren rasyonlarla beslenen farklı canlı ağırlıklara sahip hayvanlarda her iki faktörün birlikte performans üzerine etkisi önemsiz bulunmuştur. Humat seviyesinin yem tüketimi ve yemden yaralanma üzerine etkisi çok önemli olmasına rağmen, diğer parametreler humat seviyesinden önemli derecede etkilenmemiştir. Çizelge 3'de hafif, orta ve ağır şeklinde oluşturulan gruplarda canlı ağırlığın performans özellikleri üzerine etkisi çok önemli olmuştur $(\mathrm{P}<0.01)$. En yüksek yem tüketimi humat içermeyen rasyonla beslenen kontrol grubunda olmuş ve gruplar arasındaki farklar önemli bulunmuştur $(\mathrm{P}<0.01)$. Yem tüketimi ile ilgili değerler, değişik seviyelerde humat içeren rasyonların performans ve yumurta kalite özellikleri üzerine etkilerini araştıran Yörük vd. (2004) ile Küçükersan vd. (2003)'nin bulgularından düşük, Hayırlı vd.(2005) ile Ceylan vd. (2003)'nın bulgularıyla benzer, Macit vd. (2005) ile Öztürk ve Coskun (2005)'un bulgularından ise yüksek olmuştur. Yem tüketimi canlı ağırlık arttıkça artmış olup elde edilen veriler, Harms et al. (1982) ve Leeson et al. (1987) tarafindan bildirilen değerlerden yüksek bulunmuştur. Yumurta verimi bakımından değişik seviyelerde humat içeren rasyonlarla beslenen gruplar arasındaki farklılıklar önemsiz olmuştur. Ceylan vd. (2003) humatın yumurta verimine etkisinin önemli olmadığını ifade etmişlerdir. Canlı ağırlık arttıkça yumurta verimi de artmıştır. Leeson et al. (1987) yumurta veriminin, ağır gruplarda daha fazla olduğunu bildirmişlerdir. Ancak. Harms et al. (1982) canlı ağırlığın yumurta verimi üzerine etkisinin olmadığını ifade etmişlerdir. Humat seviyesine göre deneme grupları arasında yumurta ağırlığı ortalamaları bakımından önemli istatistiksel olarak bir fark gözlenmemiştir. Bir çok araştırmacı tarafindan yürütülen çalışmalardan elde edilen bulgular mevcut çalışmadan elde edilen bulguları desteklemektedir (Ceylan vd., 2003; Küçükersan vd., 2003; Yörük vd., 2004; Hayırlı vd., 2005; Macit vd., 2005). Çizelge 3 'de, ortalama yumurta ağırlıkları hafif, orta ve ağır deneme gruplarında sırasıyla 61.3. 60.2. ve $62.7 \mathrm{~g}$ bulunmuş ve yumurta ağırlığı değerleri bakımından gruplar arasında tespit edilen farkların istatistiksel olarak önemli olduğu gözlenmiştir. Elde edilen değerler. Leeson et al. (1987) ve Harms et al. (1982)'nın bildirmiş oldukları değerlerden yüksek bulunmuştur. Yemden yararlanma oranları bakımından gruplar arasındaki farklar önemli olmuştur $(\mathrm{P}<0.01)$. Yumurtacı tavuk rasyonuna katılan değişik seviyelerdeki humatın yemden yararlanmayı olumlu yönde etkilemesi, humatın performans üzerine etkisini araştıran araştırmacılar tarafından bildirilen sonuçlarla uyum göstermiştir (Küçükersan vd.. 2003; Yörük vd.. 2004; Hayırlı vd.. 2005; Macit vd.. 2005). Yemden yararlanma oranları $\%$ 0. 0.15 ve 0.30 humat içeren rasyonlarla beslenen gruplarda, sırasıyla $2.0,2.0$ ve 2.8 olarak tespit edilmiştir. Mevcut çalışmadan elde edilen sonuçlar Macit vd. (2005), Ceylan vd. (2003) ile Küçükersan vd. (2003)'nin bulgularıla benzer, Yörük vd. (2004) ile Öztürk ve Coşkun (2005)'un bulgularından düşük, Hayırlı vd. (2005)'nin bulgularından ise yüksek olmuştur. Canlı ağırlık arttıkça bir kilogram yumurta üretimi için tüketilen yem miktarı da artmıştır (Çizelge 3). Canlı ağırlığın yemden yararlanma üzerine etkisi önemli bulunmuştur $(\mathrm{P}<0.01)$. Harms et al. (1982) tarafından elde edilen bulgular, mevcut çalışmadan elde edilen değerlerle benzerlik göstermiştir. Canlı ağırlık artışı, rasyona katılan humat seviyesinden etkilenmemiştir. Macit vd. (2005) ile Hayırlı vd. (2005)'nin yaptıkları çalışmalardan elde ettikleri sonuçlar, bu çalışmadaki bulguyla örtüşmektedir. Hafif, orta ve ağır gruplarda, canlı ağırlığın ağırlık artışı üzerine etkisinin önemli olduğu tespit edilmiştir $(\mathrm{P}<0.01)$. Bu çalışmadan elde edilen değerler, Harms et al. (1982)'in bulgularıyla benzerlik göstermektedir.

Yumurta kalite kriterleri olarak ele alınan özelliklere ait ortalama ve standart hatalar ile çoklu karşılaştırma testi sonuçları Çizelge 4'de verilmiştir. 
Çizelge 4. Deneme gruplarının yumurta kalite özelliklerine ait ortalamalar

\begin{tabular}{|c|c|c|c|c|c|c|c|c|c|}
\hline \multicolumn{2}{|c|}{ Muamele } & \multicolumn{8}{|c|}{ Yumurta Kalite Özellikleri } \\
\hline $\begin{array}{l}\text { Humat } \\
\text { Seviyesi } \\
(\%)\end{array}$ & $\begin{array}{l}\text { Canlı } \\
\text { ağırlık } \\
(\mathrm{g})\end{array}$ & $\begin{array}{l}\text { Yumurta } \\
\text { ağırliğg1 } \\
\text { (g) }\end{array}$ & $\begin{array}{c}\text { Şekil } \\
\text { indeksi } \\
(\%)\end{array}$ & $\begin{array}{l}\text { K1r1lma } \\
\text { mukavemeti } \\
\mathrm{Kg} / \mathrm{cm}^{2}\end{array}$ & $\begin{array}{l}\text { Kabuk } \\
\text { kalınlığ } 1 \\
\mathrm{~mm} \times 10^{-2}\end{array}$ & $\begin{array}{l}\text { Sar1 } \\
\text { rengi }\end{array}$ & $\begin{array}{l}\text { Ak } \\
\text { İndeksi } \\
(\%)\end{array}$ & $\begin{array}{l}\text { Sar1 } \\
\text { indeksi } \\
(\%)\end{array}$ & $\begin{array}{l}\text { Haugh } \\
\text { Birimi }\end{array}$ \\
\hline \multirow[t]{3}{*}{$\% 0$} & Hafif & 61.49 & 76.229 & 2.617 & 1.175 & 10.258 & 9.134 & 44.07 & 85.369 \\
\hline & Orta & 59.89 & 76.229 & 2.357 & 1.180 & 9.833 & 9.780 & 44.24 & 86.320 \\
\hline & $\overline{A \breve{g} ı r}$ & 61.67 & 75.500 & 2.433 & 1.140 & 10.375 & 8.618 & 43.57 & 82.193 \\
\hline \multicolumn{2}{|c|}{ Ortalama } & 61.02 & 75.99 & 2.47 & 1.16 & $10.16^{\mathrm{B}}$ & 9.18 & $43.9^{A}$ & 84.63 \\
\hline \multirow[t]{3}{*}{$\% 0.15$} & Hafif & 60.51 & 76.271 & 2.460 & 1.164 & 10.583 & 9.358 & 43.07 & 84.639 \\
\hline & Orta & 60.86 & 75.375 & 2.648 & 1.183 & 10.508 & 9.202 & 40.91 & 84.344 \\
\hline & Ağır & 62.22 & 75.875 & 2.357 & 1.166 & 10.667 & 9.870 & 44.03 & 86.350 \\
\hline \multicolumn{2}{|c|}{ Ortalama } & 61.20 & 75.84 & 2.49 & 1.17 & $10.59^{\mathrm{A}}$ & 9.48 & $42.6^{\mathrm{B}}$ & 85.11 \\
\hline \multirow[t]{3}{*}{$\% 0.30$} & Hafif & 61.89 & 75.771 & 2.504 & 1.175 & 10.458 & 9.870 & 44.85 & 86.659 \\
\hline & Orta & 59.88 & 76.083 & 2.560 & 1.167 & 10.917 & 8.963 & 43.67 & 83.130 \\
\hline & Ăğır & 64.20 & 76.000 & 2.543 & 1.189 & 10.558 & 9.995 & 44.35 & 87.273 \\
\hline \multicolumn{2}{|c|}{ Ortalama } & 61.99 & 75.95 & 2.54 & 1.18 & $10.64^{\mathrm{A}}$ & 9.61 & $44.2^{\mathrm{A}}$ & 85.69 \\
\hline \multicolumn{2}{|c|}{$\mathrm{S} \bar{x}$} & .849 & .448 & .162 & .014 & .227 & .362 & .791 & 1.301 \\
\hline \multicolumn{10}{|l|}{$\bar{P}$} \\
\hline \multicolumn{2}{|c|}{ Humat seviyesi } & 0.328 & 0.917 & 0.869 & 0.550 & 0.015 & 0.320 & 0.028 & 0.580 \\
\hline \multicolumn{2}{|c|}{ A ğırlık } & 0.002 & 0.709 & 0.775 & 0.565 & 0.794 & 0.812 & 0.168 & 0.626 \\
\hline \multicolumn{2}{|c|}{ Seviye $\times$ ağırlık } & 0.296 & 0.502 & 0.619 & 0.154 & 0.253 & 0.021 & 0.187 & 0.012 \\
\hline \multicolumn{2}{|c|}{ Zaman } & 0.000 & 0.012 & 0.047 & 0.002 & 0.008 & 0.000 & 0.000 & 0.000 \\
\hline \multicolumn{2}{|c|}{ Seviye $\times$ zaman } & 0.943 & 0.541 & 0.025 & 0.536 & 0.138 & 0.642 & 0.359 & 0.772 \\
\hline \multicolumn{2}{|c|}{ Ağırlık $\times$ zaman } & 0.495 & 0.133 & 0.379 & 0.711 & 0.056 & 0.780 & 0.910 & 0.169 \\
\hline \multicolumn{2}{|c|}{ Seviye $\times$ ağırlık $\times$ zaman } & 0.887 & 0.563 & 0.784 & 0.600 & 0.196 & 0.756 & 0.077 & 0.926 \\
\hline
\end{tabular}

A.B: Aynı sütunda farklı harflerle gösterilen ortalamalar arasındaki farklılıklar önemlidir ( $\mathrm{P}<0.01)$.

Rasyona çeşitli seviyelerde humat ilavesinin yumurta kalitesi ile ilgili özelliklerinden yumurta ağırlığı, şekil indeksi, kırılma mukavemeti, kabuk kalınlığı, ak indeksi ve Haugh birimi değerlerini etkilemediği tespit edilmiştir. Yumurta sarı rengi değerleri bakımından gruplar arasındaki farklar önemli bulunmuştur $(\mathrm{P}<0.05)$. Gruplar arasında en düşük sarı rengi değeri kontrol grubunda saptanırken, humat içeren diğer iki grup sarı rengi değeri bakımından benzerlik göstermiştir. Macit vd. (2005) ile Ceylan vd. (2003) yemlere humat ilavesiyle yumurta sarı renginde daha koyu renk oluştuğunu ifade ederken, Yörük vd. (2004) ile Hayırlı vd. (2005) humat ilavesinin sarı rengi değerlerini etkilemediğini belirtmişlerdir. Bu çalışmada sarı indeksi bakımından gruplar arasında gözlenen farklılıklar önemli olmuştur $(\mathrm{P}<0.05)$. Elde edilen sarı indeksi değerleri Macit vd.(2005)'nin bulgularından yüksek, Yörük vd. (2004) ile Küçükersan vd. (2003)'nin değerleri ile benzer bulunmuştur. Hafif, orta ve ağır şeklinde oluşturulan deneme gruplarında, yumurta ağırlığ1 dışındaki yumurta kalite kriterlerinin canlı ağırlıktan etkilenmediği tespit edilmiştir. Canlı ağırlığı yüksek olan tavuk grubunun, diğer canlı ağırlık gruplarına göre daha ağır yumurta verdikleri belirlenmiştir. Mevcut çalışmada humat seviyesi ve canlı ağırlığın birlikte etkisi sadece ak indeksi ve haugh birimi üzerinde olmuştur.

Mevcut çalışmadan elde edilen bulgular; rasyona humat ilavesinin yem tüketimi, yemden yaralanma, sarı rengi ve sarı indeksini iyileştirdiğini ve yüksek canlı ağırlığın ise bütün performans özelliklerinde negatif yönde etkili olduğu ortaya konulmuştur. Her iki faktörün birlikte etkisi, Haugh birimi ve ak indeksi dışındaki özellikler üzerinde görülmemiştir.

Sonuç olarak, yumurta iç ve dış kalite özelliklerinin genel olarak rasyona humat ilavesinden ve canlı ağırlıktan etkilenmediği, humat içeren rasyonlarla beslenen gruplarda yemden yararlanmanın iyileştiği bildirilirken, deneme başı canlı ağılığı 1400$1500 \mathrm{~g}$ arasında değişen hayvanlardan oluşturulan hafif grupta yumurta verimi dışındaki performans özelliklerinin diğer gruplardan önemli seviyede $(\mathrm{P}<0.01)$ daha iyi olduğu kanaatine varılmıştır.

\section{KAYNAKLAR}

Altan, Ö., Oğuz, İ., Akbaş, Y., 1998. Japon bildırcinlarında (Coturnix coturnix japonica) canlı ağırlık yönünde yapılan seleksiyonun ve yaşın yumurta özelliklerine etkileri. Tr. J. of Vet. and Anim. Sci., 22: 467-473. 
Anonim., 2002. The effects of humates on crops. Web site (http://www.organicapproacn.com/ humates.htm). (Erişim Tarihi:01.02.2019)

Arafa, A.A., Hassanien, F.M., Harn, R.N., 1982. Relationship between age of hens. egg spesific gravity and time of day to severity pimpling of egg shell. Poult. Sci., 61: 385-387.

Bailey, C.A., White, K.E., Domke, S.L., 1996. Evaluation of Menefee Humate on The Performance of Broilers. Poult. Sci., 75 (1): 84.

Ceylan, N., Çiftçi, İ., Kahraman, Z., Mızrak, C., 2003. Yumurta tavuğu yemlerinde humat bileşikler kullanımının performans yumurta kalitesi ve bağırsak mikroflorası üzerine etkileri. II. Ulusal Hayvan Besleme Kongresi, 18-20 Eylül, 2003, Konya, s: 163-168.

Harms, R.H., Costa, P.T., Miles, R.D., 1982. Daily Feed Intake and Performance of Laying Hens Grouped According to Their Body Weight. Poult. Sci., 61: 1021-1024

Hayırll, A., Esenbuğa, N., Macit, M., Laçin, E., Karaoğlu, M., Karaca, H., Yıldız, L., 2005. Nutrition practice to alleviate the adverse effects of stress on laying performance. metabolic profile and egg quality in peak producing hens: I. The humate supplementation. Asian-Aust. J. Anim. Sci., 18 (9) : 1310-1319.

Humik, J. F., Summers, J.D., Reinhard, B.S., Sweirczewks, A., 1977. Effects of age in the performance of laying hens during the first year of production. Poult. Sci., 56: 222-230.

Kaya, H., Macit, M., 2012. Effect of inclusion of garlic (Allium sativum) powder at different levels and copper into diets of hens on performance, egg quality traits and yolk cholesterol content. Int. J. of Poult. Sci., 11 (2): 114-119.
Küçükersan, S., Küçükersan, K., Göncüoğlu, E., Şahin, T., 2003. Yumurta tavuğu rasyonlarına ilave edilen humatların yumurta verimi ve kalitesine etkisi. III Ulusal Hayvan Besleme Kongre Bildiriler Kitabı, 7-10 Eylül, 2003, Adana, s: $168-173$.

Leeson, S., Summers, J.D., 1987. Effect of immature body weight on laying performance. Poult. Sci., 66 (12): 1924-1928.

Levinsky, B.V., 1997. All About Humate Effects and Benefits. Web Site: (http://www.Humic.com/). (Erişim Tarihi: 15.01.2019)

Macit, M., Çelebi, Ş., Esenbuğa, N., Karaca, H., 2005. Yumurtacı tavuk rasyonlarına farklı oranlarda katılan humatların performans yumurta kalitesi ve yağ asidi kompozisyonu üzerine etkileri. III. Ulusal Hayvan Besleme Kongresi, 7-10 Eylül, 2005, Adana, s: 300-306.

Öztürk, E., Coşkun, İ., 2005. Humik asitler içeren bitki extractının yumurta tavuklarının yumurta verimi ve kalitesine etkileri. . III. Ulusal Hayvan Besleme Kongresi, 7-10 Eylül, 2005, Adana, s: 188-191.

Parks, C., Ferket, P.R., Thomas, L.N., Grimes, J.L., 1996. Growth performance and immunity of turkey fed high and low crude protein diets supplemented with Menefee humate. Poult. Sci., 75 (Suppll 1): 138.

Roland, D.A., 1979. Factors influencing shell quality of aging hens. Poult. Sci., 58: 774-777.

SAS Institute, 1998. SAS User's Gudie: Statistics. Version 7th. SAS Institute Inc., Cary, NC.

Yörük, M.A., Gül, M., Hayırlı, A., Macit, M., 2004. The effects of supplementation of humate and probiotic on egg production and quality parameters during the late laying period in hens. Poult. Sci., 83: 84-88. 